\title{
TECHNOLOGICAL AND CHEMICAL STUDY ON WHITE CHEESE (QUESO BLANCO): \\ 1- EFFECT OF COAGULATING AGENT ON QUESO BLANCO CHEESE PROPERTIES MADE FROM COWS OR BUFFALOES MILK.
}

El-Zoghby, A. S. * ; A. M. Gamal El-Din** and W. E. El-Sharaihy**

* Dairy Technology Dept., Animal Prod. Res. Inst., Agric ., Res ., Center

** Dairy Dept ., Fac ., of Agric ., Al-Azhar Univ .

\begin{abstract}
Queso Balanco cheese made from cows or buffaloes milk standardized to $3 \%$ fat. As acidulants three organic acids namely, lactic , Citric and acetic acids were applied while, to the fourth treatment, pure yoghurt culture was added to the milk at $42 \mathrm{C}^{\circ}$ for acid development to reach $0.35 \%$ acidity. Samples of fresh , 7, 14 and 21 days were chemically, microbilogically and organoleptically analysed. Results obtained showed that yield of buffaloes milk cheese was higher than those of cows milk cheese. The addition of yoghurt culture ( fourth treatment ) gave the highest yield . On the other hand cows milk cheese contained higher moisture as compared with buffaloes milk cheese. Cultured yoghurt cheese contained the highest moisture, followed by acetic , citric and lactic acid cheese, for both cows and buffaloes milk cheese. Fat content of cows milk was higher than buffaloes milk cheese owing to the high losses of buffaloes milk fat during cheese making on the other hand lactic acid cheese contained the highest fat and protein contents.While yoghurt culture cheese gave the lowest value. Buffaloes milk cheese contained higher protein content than cows milk cheese. Cows milk cheese acidity was higher than those of buffaloes milk cheese as well citric acid cheese resulted in the highest acidity for both milk while yoghurt culture cheese gave the lowest value. Buffaloes milk cheese contained higher total microbial count (T.M.C. ) than those of cows milk cheese. Cultured milk cheese contained the highest T.M.C. while, the lowest was for citric acid cheese. No moulds and yeasts were detected in fresh cheese samples while they gradually increased during the storage period. Cows milk cheese gained higher organoleptic score than those of buffaloes milk. Starter culture cheese was the best one followed by lactic, citric acid while acetic acid cheese obtained the lowest scoring points and refused by most panalists who complained the taste of rotten food (taste of cvinegar).
\end{abstract}

\section{INTRODUCTION}

Queso Blanco is generic name for white semi-soft cheese in central and south America. The name Queso Blanco covers many white cheese varaieties which differ from each other by the method of production. However the acid/ heat process is used for coagulation the milk. So, the production method of acid/ heat coagulated Queso Blanco varies but generally involves heating of the standardized milk to $82 \mathrm{C}^{\circ}$ or more , followed by the addition of acid. In Egypt the take away meals have been gradually increased during the last tow decades. The pies and cheese cakes represent a considerable part of the take away meals, were the imported acid coagulated cheese namely Recotta cheese is usually used for filling these sorts of meals. Thus, future of Queso Blanco cheese propose it for use as a filling materials for those meal 
sorts Queso Blanco normally, processed from cows milk and no available literature about the use of buffaloes milk .So, the aim of this investigation is to study the effect of type of milk on its technological, chemical, microbiological and organoleptic properties of Queso Blanco cheese .

\section{MATERIALS AND METHODS}

Buffaloes and cows milk used in the present study were obtained from the herds of El-Gemmeza, Animal Production Research Station Ministry of Agriculture, Egypt. Acidulants lactic, citric and acetic acid edible grade were bought from El-Gomhoria Company for Chemical, Cairo, Egypt. Starter used was obtained from Ch Hansen Laboratories Denmark Lypholiszed starter culture of Streptococcus saliverus sub sp thermophilus and Lactobacillus delprukii sub sp bulgaricus (1-1) were separately activated by culturing in 15 $\%$ reconstituted skim milk. Salt : Fine salt was obtained from " El-Nasr Company of Alexanderia Egypt ".

Cheese making : The method adopted for making Queso Balanco cheese was recommended by kosikowski , ( 1966 ) and modified as follows $: 3 \%$ fat of cows or buffaloes milk were used.: The organic acids were diluted $1: 3$ then separately added to the heated milk at $82 \mathrm{C}^{\circ}$ stirring three minutes for complete coagulation then $3 \%$ salt were added, the curd was left at this temperature for 15 minutes filled in special allumonium hoops, pressed by a weight equal to $50 \%$ of the milk weight. The following day, the cheese is stored at refrigerator at $5 \pm 1 \mathrm{C}^{\circ}$ for 21 days .

Four batchs of cows milk each $20 \mathrm{~kg}$ were processed to Queso Blanco cheese. To the first lacitic acid was added and regarded as control , while to the second ,third and fourth vats citric, acetic acids and youghurt culture starter were added respectively. The fourth treatment was processed when the acidity of cultured milk reached $0.35 \pm 0.01 \%$. Similar to cows milk four paches of buffaloes milk were parallely applied. The blocks of cheese packed under vacium and stored at $5 \pm 1 \mathrm{C}^{\circ}$.

Cheese samples were examined for the moisture ,fat content ,total nitrogen ( TN ), soluble nitrogen ( SN ) non protein nitrogen ( NPN ), PH value and titratable acidity, according to the methods described by Ling (1958) Salt content was estimated according to the method discribed by Kosikowski (1979) . Total volatile fatty acids ( TVFA ) was determined according to Ostoewx et al ( 1958 ) with some modification described by El-Nemre ( 1968 ). Lactose content was determined as given by Barnett and Abd El-Twab ( 1957 ). Total bacterial count were achieved according to Difco Manual (1971 ). Moulds \& Yeasts counts were determined using malt extract agar medium Pitt (1979). The organoleptic properties of cheese were evaluated according to method of Scott (1981).

Cheese samples were chemically, microbiologically and organoleptically analysed for fresh, 7, 14 and 21 days old cheese. 


\section{RESULT AND DISCUSSION}

Chemical analysis of different whey are shown in ( Table 1). The total solids (TS) of cows milk cheese was whey higher than those of buffaloes milk cheese , El-Zoghby ( 1994 ) found $6.62 \%$ and $4.15 \%$ TS for buffaloes and cows milk whey of Mozzarella cheese respectively. The acetic acid treatment gave also higher TS , while the lowest TS was for lactic acid and the medium was for citric acid treatments. Starter culture gave higher TS . The losses of fat was higher in whey of buffaloes milk than cows milk cheese and higher in starter culture treatments than other acids. Abdel - Kader ( 1993 ) found higher losses in fat into whey of buffaloes milk than cows milk of Kachkaval cheese. The highest loss was in acetic acid treatment followed by citric and lactic acid. The protein content was higher in cows milk whey than buffaloes treatment and whey of starter culture treatments contained higher protein than whey of other acids. Acidity of buffaloes milk whey was less than cows milk whey and the lowest one was for starter culture treatment as compared with other acidulants whey

Table (1): The chemical composition of released whey (Average of 3 replicates)

\begin{tabular}{|c|c|c|c|c|c|c|c|c|}
\hline \multirow{3}{*}{ Composition } & \multicolumn{8}{|c|}{ Treatments } \\
\hline & \multicolumn{4}{|c|}{ Cow's } & \multicolumn{4}{|c|}{ Buffaloes } \\
\hline & 1 & 2 & 3 & 4 & 1 & 2 & 3 & 4 \\
\hline TS \% & 7.16 & 7.22 & 7.29 & 7.35 & 6.11 & 6.19 & 6.29 & 6.46 \\
\hline Fat \% & 0.52 & 0.56 & 0.59 & 0.64 & 0.65 & 0.69 & 0.72 & 0.79 \\
\hline Fat /DM \% & 7.30 & 7.78 & 8.16 & 8.77 & 10.63 & 11.14 & 11.48 & 12.22 \\
\hline TN \% & 0.084 & 0.089 & 0.097 & 0.109 & 0.053 & 0.060 & 0.068 & 0.080 \\
\hline TN /DM \% & 0.535 & 0.568 & 0.621 & 0.696 & 0.342 & 0.385 & 0.439 & 0.514 \\
\hline Acidity \% & 0.33 & 0.38 & 0.35 & 0.26 & 0.30 & 0.36 & 0.31 & 0.22 \\
\hline $\mathrm{pH}$ & 5.46 & 5.39 & 5.41 & 5.64 & 5.48 & 5.32 & 5.42 & 5.68 \\
\hline $\begin{array}{l}\text { =Lactic acid } \\
=\text { Citric acid } \\
=\text { Acetic acid }\end{array}$ & \multicolumn{8}{|c|}{$\begin{array}{l}\text { TS= total solids } \\
\text { DM= Dry matter } \\
\text { TN= total nitrogen }\end{array}$} \\
\hline
\end{tabular}

Yield, moisture, acidity, and $\mathrm{PH}$ values of different cheese are presented in (Table 2). The yield of buffaloes milk cheese was higher ( 15.87 $-16.50 \%)$ for fresh cheese than those of fresh cows milk $(12.0-12.62 \%)$ The use of starter culture resulted in raising the yield of both milk cheese , while control cheese ( Lactic acid) gave the lowest value .Kosikowski (1966) mentioned that from $2.2 \%$ fat milk , the yield of similar cheese was $11.6 \%$ when glacial acetic acid was used as acidulant. The moisture content for fresh cheese was higher in cows milk cheese ( $56.41-58.27 \%$ ) than buffaloes milk cheese ( $52.18-54.35 \%$ ) The addition of starter culture gave the highest moisture content followed by acetic , citric , and lactic acid cheese for both cows or buffaloes milk cheese. As ripening period progressed moisture content decreased. El-Hofi et al (1991) and Mohamed et al (1999) stated that decreased of moisture content was sharp during the first month follow by gradual decrease during the rest period of ripening . It is clear from 
the data that yoghurt culture starter cheese had the lowest acidity values 0.30 and $0.27 \%$ for fresh cows and buffaloes milk cheese respectively. Citric acid possessed higher acidity. PH values of different treatments decreased as storage time increased. Chandan et al ( 1979 ) reported that $\mathrm{PH}$ value of Queso Blanco cheese were ranged from $4.9-5.2,5.0-5.2,4.7-5.3,4.9$ -5.0 and 5.0 to 5.3 when acidulants ,citric, $\mathrm{HCL}$, lactic , acetic and tartaric acids were used respectively

Table (2): Effect of coagulating agent on yield, moisture, acidity and $\mathrm{pH}$ values of Queso Blanco cheese (Average of 3 replicates).

\begin{tabular}{|c|c|c|c|c|c|c|c|c|c|}
\hline \multirow{3}{*}{ Composition } & \multirow{2}{*}{$\begin{array}{l}\begin{array}{c}\text { Storage } \\
\text { period } \\
\text { (days) }\end{array} \\
\end{array}$} & \multicolumn{8}{|c|}{ Treatments } \\
\hline & & \multicolumn{4}{|c|}{ Cows } & \multicolumn{4}{|c|}{ Buffaloes } \\
\hline & \multirow{5}{*}{ Fresh } & 1 & 2 & 3 & 4 & 1 & 2 & 3 & 4 \\
\hline Yield \% & & 12.00 & 12.37 & 12.62 & 13.12 & 15.87 & 16.12 & 16.5 & 17.12 \\
\hline Moisture \% & & 56.41 & 57.18 & 58.27 & 59.15 & 52.18 & 53.05 & 54.35 & 55.39 \\
\hline Acidity \% & & 0.43 & 0.48 & \begin{tabular}{|l|}
0.46 \\
\end{tabular} & 0.30 & 0.40 & 0.44 & 0.41 & 0.27 \\
\hline $\mathrm{pH}$ values & & 5.35 & 4.93 & 5.30 & 5.43 & 5.48 & 4.53 & 5.50 & 5.38 \\
\hline Yield \% & \multirow{4}{*}{7} & 11.87 & 12.12 & 12.50 & 12.87 & 15.87 & 16.00 & 16.31 & 16.87 \\
\hline Moisture \% & & 55.85 & 56.71 & 57.64 & 59.31 & 51.55 & 53.63 & 53.89 & 55.03 \\
\hline Acidity \% & & 0.40 & 0.53 & 0.46 & 0.35 & 0.44 & 0.47 & 0.44 & 0.32 \\
\hline $\mathrm{pH}$ values & & 5.29 & 4.93 & 5.30 & 5.43 & 5.38 & 4.97 & 5.32 & 5.43 \\
\hline Yield \% & \multirow{4}{*}{14} & 11.50 & 11.81 & 12.12 & 12.62 & 15.25 & 15.62 & 16.00 & 16.75 \\
\hline Moisture \% & & 55.49 & 56.24 & 57.12 & 58.81 & 51.28 & 52.24 & 53.64 & 54.45 \\
\hline Acidity \% & & 0.49 & 0.57 & \begin{tabular}{|l|}
0.51 \\
\end{tabular} & 0.39 & 0.47 & 0.49 & 0.48 & 0.35 \\
\hline $\mathrm{pH}$ values & & 5.24 & 4.80 & 5.18 & 5.33 & 5.27 & 4.84 & 5.21 & 5.33 \\
\hline Yield \% & & 11.35 & 11.43 & 11.87 & 12.00 & 14.75 & 15.37 & 15.62 & 16.55 \\
\hline Moisture \% & & 54.78 & 56.05 & 56.67 & 58.28 & 50.71 & 51.68 & 53.08 & 53.65 \\
\hline Acidity \% & & 0.51 & 0.60 & 0.53 & 0.43 & 0.48 & 0.53 & 0.50 & 0.38 \\
\hline $\mathrm{pH}$ values & & 5.18 & 4.73 & 4.73 & 5.12 & 5.22 & 4.77 & 5.16 & 5.27 \\
\hline
\end{tabular}

Table (3) illustrated fat, total nitrogen, lactose and salt contents of cheese during ripening. The fat content of cows milk cheese was higher than those of buffaloes milk cheese. Comparing between acidulants, lactic acid cheese ( cows or buffaloes ) contained the highest fat /DM content, while acetic acid cheese contained the lowest fat/DM content . Comparing between acid and pure starter , the starter cheese contained the lowest fat content for both types of milk cheese ( cows or buffaloes ). Fat/DM was the highest for cows milk cheese ( $38.4 \%$ ). Similar results for buffaloes were ( 31.3 and 30.0 ) for the highest and lowest. Total nitrogen of different cheese apparently increased as storage period progressed. In general buffaloes milk cheese contained higher TN/DM $(8.09-8.23 \%)$ than cows milk cheese ( $7.24-$ 7.55 ). Among acids, it is observed that lactic acid treatment contained the highest TN/DM \% while cultured milk cheese contained the lowest value. After 21 days of storage TN/DM \% values were $7.87,7.79,7.66$ and 7.50 for lactic, citric, acetic, and culture milk cheese respectively .Respective values for buffaloes milk were $8.46,8.41,8.37$ and $8.29 \%$ respectively . Robinson and Tamime ( 1991 ) reported that Queso Blanco cheese are containing higher protein than fat content. The lactose content was generally higher in 
buffaloes milk cheese, lactose/DM was ( $5.58-6.62 \%$ ) for buffaloes and ( $4.48-5.09 \%$ ) for cows milk cheese. Acetic acid buffaloes cheese contained the highest lactose/DM ( $6.02 \%$ ) while for cows milk cheese citric acid treatment gave the highest lactose/DM (5.09\%). Kosikowski ( 1966 ) reported that lactose content of Queso Blanco cheese ranged between (1.8$2.0 \%)$ Salt/Moisture content ranged between ( $4.02-4.69 \%)$ in fresh buffaloes milk cheese while ranged $(3.60-4.09 \%)$ in fresh cows milk cheese. As ripening period progress Salt/M increased.

Table (3) : Effect of coagulation agent on fat, total protein (TN), lactose and salt contents of Quese Blanco chesse (Average of replicates).

\begin{tabular}{|c|c|c|c|c|c|c|c|c|c|}
\hline \multirow[t]{2}{*}{ Composition } & \multirow{2}{*}{$\begin{array}{c}\text { Storage } \\
\text { period } \\
\text { (days) }\end{array}$} & \multicolumn{8}{|c|}{ Treatments } \\
\hline & & \multicolumn{4}{|c|}{ Cows } & \multicolumn{4}{|c|}{ Buffaloes } \\
\hline \multirow{5}{*}{ Fat / DM \% } & & 1 & 2 & 3 & 4 & 1 & 2 & 3 & 4 \\
\hline & Fresh & 39.45 & 9.23 & 39.06 & 38.41 & 31.36 & 31.09 & 30.66 & 3.03 \\
\hline & 7 & 39.86 & 39.50 & 39.42 & 38.58 & 31.57 & 31.24 & 31.01 & 30.24 \\
\hline & 14 & 40.03 & 39.76 & 39.64 & 38.84 & 32.01 & 31.61 & 31.49 & 30.60 \\
\hline & 21 & 40.68 & 40.04 & 39.92 & 39.54 & 32.46 & 32.28 & 31.96 & 31.06 \\
\hline \multirow{4}{*}{ TN/DM \% } & Fresh & 7.55 & 7.49 & 7.40 & 7.24 & 8.28 & 8.23 & 8.16 & 8.09 \\
\hline & 7 & 7.64 & 7.52 & 7.45 & 7.39 & 8.32 & 8.29 & 8.23 & 8.14 \\
\hline & 14 & 7.73 & 7.65 & 7.52 & 7.42 & 8.41 & 8.37 & 8.29 & 8.18 \\
\hline & 21 & 7.87 & 7.79 & 7.66 & 7.56 & 8.46 & 8.41 & 8.37 & 8.29 \\
\hline \multirow{4}{*}{$\begin{array}{c}\text { Lactose / DM } \\
\%\end{array}$} & Fresh & 4.58 & 5.09 & 5.00 & 4.48 & 5.89 & 5.58 & 6.02 & 5.58 \\
\hline & 7 & 4.46 & 4.68 & 4.72 & 4.25 & 5.67 & 5.44 & 5.81 & 5.35 \\
\hline & 14 & 4.31 & 4.45 & 4.50 & 4.00 & 5.54 & 5.23 & 5.65 & 5.11 \\
\hline & 21 & 4.09 & 4.25 & 4.17 & 3.71 & 5.35 & 5.02 & 5.41 & 4.85 \\
\hline \multirow{4}{*}{$\begin{array}{c}\text { Salt in } \\
\text { moisture \% }\end{array}$} & Fresh & 4.09 & 3.96 & 3.77 & 3.60 & 4.69 & 4.56 & 4.32 & 4.02 \\
\hline & 7 & 4.22 & 4.05 & 3.92 & 3.67 & 4.83 & 4.63 & 4.47 & 4.16 \\
\hline & 14 & 4.32 & 4.23 & 4.04 & 3.88 & 4.47 & 4.76 & 4.58 & 4.27 \\
\hline & 21 & 4.54 & 4.31 & 4.21 & 3.99 & 5.10 & 4.95 & 4.76 & 4.49 \\
\hline
\end{tabular}

Soluble nitrogen/TN, NPN/TN and TVFA are tabulated in ( Table 4 ) .Type of acid has a clear effect on the SN, NPN contents of the cheese . Among the three acids, acetic cheese contained the highest SN/TN and NPN/TN for both types of cheese, while lactic acid cheese contained the lowest amount of SN/TN and NPN/TN contents .

On the other hand, the use of yoghurt culture starter led to higher SN/TN and NPN/TN contents in buffaloes milk cheese but still values are less of those of cows milk cheese. El-Zoghby ( 1994 ) indicated that SN/TN and NPN/TN of Mozzarella cheese increased as ripening time increased SN and NPN buffaloes milk cheese were developed slower than cows milk cheese. Total volatile fatty acids ( TVFA ) of yoghurt culture starter cheese was higher for both types of milk cheese. As storage time increased TVFA also increased. The TVFA for cows milk were higher than Buffaloes milk cheese and control cheese (lactic acid treatment) showed the lowest values for both milk the highest was for yoghurt culture starter milk cheese in both type of milk . 
El-zoghby, A. S. et al.

Table (4): Effect of coagulating agent on soluble nitrogen (SN), non protein nitrogen (NPN) and total volatile fatty acid (TVFA) of Queso Blanco cheese (Average of 3 replicates).

\begin{tabular}{|c|c|c|c|c|c|c|c|c|c|}
\hline Composition & $\begin{array}{l}\text { Storage } \\
\text { period } \\
\text { (days) }\end{array}$ & \multicolumn{6}{|c|}{ Cows } & \multicolumn{4}{c|}{ Buffaloes } \\
\cline { 2 - 10 } & & $\mathbf{1}$ & $\mathbf{2}$ & $\mathbf{3}$ & $\mathbf{4}$ & $\mathbf{1}$ & $\mathbf{2}$ & $\mathbf{3}$ & $\mathbf{4}$ \\
\hline \multirow{4}{*}{ SN/TN \% } & Fresh & 7.13 & 8.35 & 9.22 & 10.57 & 4.06 & 4.76 & 5.57 & 6.97 \\
\cline { 2 - 10 } & 7 & 7.76 & 8.74 & 9.56 & 11.43 & 4.56 & 5.11 & 6.19 & 7.58 \\
\cline { 2 - 10 } & 14 & 8.23 & 9.24 & 10.41 & 12.07 & 5.14 & 6.02 & 6.81 & 8.17 \\
\cline { 2 - 10 } & 21 & 9.43 & 10.27 & 11.29 & 12.85 & 5.63 & 6.83 & 7.86 & 9.33 \\
\hline \multirow{4}{*}{ NPN/TN \% } & Fresh & 4.07 & 5.23 & 6.27 & 7.45 & 2.52 & 3.02 & 3.78 & 4.80 \\
\cline { 2 - 10 } & 7 & 4.76 & 5.66 & 6.68 & 8.19 & 3.14 & 3.40 & 4.50 & 5.48 \\
\cline { 2 - 10 } & 14 & 5.31 & 6.73 & 7.37 & 8.76 & 3.68 & 4.20 & 5.04 & 6.30 \\
\cline { 2 - 9 } & 21 & 6.12 & 7.35 & 8.05 & 9.87 & 4.26 & 4.94 & 4.54 & 7.07 \\
\hline \multirow{4}{*}{ TVFA * } & Fresh & 14.0 & 20.8 & 16.4 & 24.0 & 4.0 & 12.0 & 10.0 & 16.4 \\
\cline { 2 - 9 } & 7 & 17.6 & 23.2 & 20.0 & 26.4 & 8.0 & 14.8 & 12.4 & 18.8 \\
\cline { 2 - 9 } & 14 & 20.4 & 26.0 & 23.6 & 28.4 & 11.2 & 18.0 & 16.0 & 21.2 \\
\cline { 2 - 9 } & 21 & 24.0 & 30.8 & 28.0 & 33.2 & 16.0 & 21.2 & 19.2 & 24.8 \\
\hline
\end{tabular}

${ }^{*} \mathrm{ml} 0.1 \mathrm{~N} \mathrm{NaOH} / 100$

Total bacterial counts and Moulds \& Yeasts (Table 5) deals with total bacterial counts as well Moulds \& Yeasts of different cheese during the storage period of 21 days. Although the acidified milk was heated up to $82 \mathrm{C}^{\circ}$ for some minutes, some bacteria resisted this conditions, total microbial count for fresh cheese ranged between $\left(4.13 \times 10^{4}-7.92 \times 10^{4}\right)$ for cows milk fresh cheese and $\left(7.82 \times 10^{4}-10.15 \times 10^{4}\right)$ colony forming unit CFU/gm of buffaloes milk cheese. Yoghurt culture starter treatments contained the higest $\mathrm{CFU} / \mathrm{gm}$ for both milk cheese. No colonies of Mould \&Yeast were observed in all fresh treatments and started to appear after 7 days of storage. Abdel Kader (1993) found that addition of different acidulant decreased the total microbial count of starter, citric acid had a severe inhibition for bacterial followed by acetic acid and finally HCL. As well buffaloes milk contained higher CFU/gm than cows milk.

Table (5): Total bacterial count (T.C) and Mould \& Yeast of Queso Blanco cheese (Average of 3 replicates).

\begin{tabular}{|c|c|c|c|c|c|c|c|c|c|}
\hline \multirow{3}{*}{$\begin{array}{l}\text { Compos- } \\
\text { ition }\end{array}$} & \multirow{3}{*}{$\begin{array}{l}\text { Storage } \\
\text { period } \\
\text { (days) }\end{array}$} & \multicolumn{8}{|c|}{ Treatments } \\
\hline & & \multicolumn{4}{|c|}{ Cows } & \multicolumn{4}{|c|}{ Buffalos } \\
\hline & & 1 & 2 & 3 & 4 & 1 & 2 & 3 & 4 \\
\hline \multirow{4}{*}{ T.C } & Fresh & $7.20 \times 10^{4}$ & $4.13 \times 10^{4}$ & $6.41 \times 10^{4}$ & $7.92 \times 10^{4}$ & $9.43 \times 10^{4}$ & $8.11 \times 10^{4}$ & $7.82 \times 10^{4}$ & $10.15 \times 10^{4}$ \\
\hline & 7 & $9.09 \times 10^{4}$ & $5.87 \times 10^{4}$ & $8.27 \times 10^{4}$ & $10.12 \times 10^{4}$ & $10.22 \times 10^{4}$ & $11.71 \times 10^{4}$ & $10.14 \times 10^{4}$ & $13.39 \times 10^{4}$ \\
\hline & 14 & $13.26 \times 10^{4}$ & $7.46 \times 10^{4}$ & $12.61 \times 10^{4}$ & $14.53 \times 10^{4}$ & $15.75 \times 10^{4}$ & $13.12 \times 10^{4}$ & $12.89 \times 10^{4}$ & $15.10 \times 10^{4}$ \\
\hline & 21 & $16.11 \times 10^{4}$ & $11.77 \times 10^{4}$ & $15.37 \times 10^{4}$ & $16.18 \times 10^{4}$ & $17.13 \times 10^{4}$ & $16.29 \times 10^{4}$ & $17.11 \times 10^{4}$ & $20.67 \times 10^{4}$ \\
\hline \multirow{3}{*}{$\begin{array}{c}\text { Mould } \\
\& \\
\text { Yeast }\end{array}$} & Fresh & N.D & N.D & N.D & N.D & N.D & N.D & N.D & N.D \\
\hline & 7 & $3.55 \times 10^{4}$ & $2.60 \times 10^{4}$ & $3.86 \times 10^{4}$ & $5.52 \times 10^{4}$ & $5.61 \times 10^{4}$ & $5.02 \times 10^{4}$ & $6.50 \times 10^{4}$ & $8.83 \times 10^{4}$ \\
\hline & 14 & $6.29 \times 10^{4}$ & $4.18 \times 10^{4}$ & $5.69 \times 10^{4}$ & $8.19 \times 10^{4}$ & $6.26 \times 10^{4}$ & $7.30 \times 10^{4}$ & $7.73 \times 10^{4}$ & $11.75 \times 10^{4}$ \\
\hline
\end{tabular}




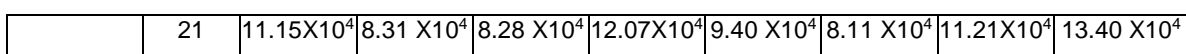

Organoleptic properties of Queso Blanco cheese are tabulated in (Table 6). In general cows milk cheese gained higher score points as compared with buffaloes milk cheese. Starter culture cheese were the best cheese followed by lactic and citric acid, while, acetic acid cheese obtained the lowest scoring points and refused by most of the pannalists who complained the taste or rotten food. It is recommended to use cows milk for processing this type of cheese because no grainy texture was detected. The use of starter culture is more safe and more economic, since the prices of ediple organic acids are very expensive as well starter bacteria had also proteolytic activity on cheese casein which gave attractive flavour to the cheese Torres and Chandan (1981) added yoghurt culture starter to the cheese curd before processing. The resultant cheese was better than control.

Table (6): Organoleptic assessment of Queso Blanco cheese (Average of 3 replicates).

\begin{tabular}{|c|c|c|c|c|c|c|c|c|c|c|}
\hline \multirow{2}{*}{\multicolumn{2}{|c|}{$\begin{array}{l}\text { Organoleptic } \\
\text { assessment }\end{array}$}} & \multirow{3}{*}{$\begin{array}{l}\text { Storage } \\
\text { period } \\
\text { (days) }\end{array}$} & \multicolumn{8}{|c|}{ Treatments } \\
\hline & & & \multicolumn{4}{|c|}{ Cows } & \multicolumn{4}{|c|}{ Buffaloes } \\
\hline & & & 1 & 2 & 3 & 4 & 1 & 2 & 3 & 4 \\
\hline \multirow{4}{*}{$\begin{array}{l}\text { A } \\
\text { B\&T } \\
F \\
T\end{array}$} & \multirow{4}{*}{$\begin{array}{r}(15) \\
(35) \\
(50) \\
(100)\end{array}$} & \multirow{4}{*}{ Fresh } & 9 & 9 & 9 & 10 & 12 & 12 & 11 & 14 \\
\hline & & & 26 & 24 & 20 & 28 & 20 & 18 & 15 & 22 \\
\hline & & & 35 & 34 & 26 & 38 & 28 & 25 & 20 & 30 \\
\hline & & & 70 & 67 & 55 & 76 & 60 & 55 & 46 & 66 \\
\hline \multirow{4}{*}{$\begin{array}{l}\text { A } \\
\text { B\&T } \\
F \\
T\end{array}$} & \multirow{4}{*}{$\begin{array}{r}(15) \\
(35) \\
(50) \\
(100)\end{array}$} & \multirow{4}{*}{7} & 8 & 8 & 8 & 9 & 11 & 11 & 12 & 13 \\
\hline & & & 27 & 25 & 21 & 29 & 22 & 20 & 16 & 24 \\
\hline & & & 38 & 36 & 27 & 41 & 31 & 27 & 23 & 33 \\
\hline & & & 73 & 69 & 56 & 79 & 64 & 58 & 49 & 70 \\
\hline \multirow{4}{*}{$\begin{array}{l}\text { A } \\
B \& T \\
F \\
T\end{array}$} & \multirow{4}{*}{$\begin{array}{r}(15) \\
(35) \\
(50) \\
(100)\end{array}$} & \multirow{4}{*}{14} & 7 & 7 & 7 & 8 & 10 & 10 & 9 & 12 \\
\hline & & & 29 & 27 & 24 & 31 & 24 & 23 & 18 & 26 \\
\hline & & & 42 & 38 & 29 & 45 & 36 & 30 & 24 & 35 \\
\hline & & & 73 & 72 & 60 & 84 & 70 & 63 & 51 & 74 \\
\hline \multirow{4}{*}{$\begin{array}{l}\text { A } \\
B \& T \\
F \\
T\end{array}$} & \multirow{4}{*}{$\begin{array}{r}(15) \\
(35) \\
(50) \\
(100)\end{array}$} & \multirow{4}{*}{21} & 6 & 6 & 6 & 7 & 9 & 9 & 8 & 11 \\
\hline & & & 31 & 30 & 26 & 34 & 28 & 26 & 19 & 31 \\
\hline & & & 44 & 41 & 33 & 49 & 39 & 35 & 26 & 40 \\
\hline & & & 81 & 77 & 65 & 90 & 76 & 70 & 53 & 82 \\
\hline
\end{tabular}

\section{REFERENCES}

Abdel-kader, Y.I.(1993 ). Technological studies on the properties of kachkaval - like cheese as affected by directacidification $\mathrm{Ph}$. D. Thesis Fac. Of Agric. Alexandria Univ., Egypt.

Barenett, A.J.G, and G. Abdel-Tawab, (1957).A rapid methods for the determination of lactose in milk and cheese. J. Sci. Food Agric. 8 July, 437-441, Egypt.

Chandan, R.C.; H. Marin; K.R. Nakrani and M.D. Zehner (1979). Production and consumer acceptance of Latin American White cheese. J. Dairy Sci. 62: 691.

Difco Manual (1971). Dehydrated culture Media and Reagent for Microbiological Clinical Laboratory Procedures. 
El-Hofi, A.A.; L.B. Abdel-Hamid; N.S. Ahmed and H.M. Abbas (1991). Acceleration of Rsa cheese ripening by relevant slury. Egyptian $\mathrm{J}$. Dariy Sc. , 19:337-346.

El-Nemr, A.A. (1968).Non enzymatic coagulation of milk and its use in soft cheese marking. Ph.D Thesis Fac. Of Agric. Cairo Univ. Egypt.

El-Zoghby, A.S. (1994). Studies on Mozzarella cheese. Ph.D Thesis Fac. of Agric. Zagazig Univ. Egypt.

Kosikowski, F.V. (1966). Cheese and fermented milk foods. $3^{\text {rd }}$ Ed, Chapman and Hall London.

Kosikowski, F.V. (1979).Mnufacture of Queso Blanco cheese and other Latin Amrican Cheese. Page 591 in Proc. 1st Bjennial Marschall Int Cheese Conf. Marschall Dairy ingred. Div., Miles lob. Ine.

Ling, E.R. (1963). A Textbook of Dairy Chemistry. Chapman and Hall Ltd. 37 Esser Street V.C. 2, Practical 1963,4 ${ }^{\text {th }}$ Edition London.

Mohamed, A.A.; H.A. Ahmed; M.S. El-Safty and I.A. Abdel-Ala (1999). Effect of using mixed steains on Ras cheese ripening . Agric. Sci. Mansoura Univ. . 24 (3):1201-1213.

Osteux, R.; J. Guillaune and J. Laturaze (1958). Separation of volatile aliphatic acids by papar chromatography. J. Chromatography, 1:70

Pitt, J.J. (1979). The genus penicillium and its telemorphic states Eu penicillium and Talaromyces London. New York Acadamic press. (c.f. Noreau 1980).

Robinson, R.K. and A.Y. Tamime (1991). Cheese made by direct acidification. I.IED. Weaton and Co. Ltd. England.

Scott, R.(1981). Cheese making practice. Aplied Sci., Publisher Ltd. London.

Torres, N. and R.C. Chandan (1981). Flavour and Texture Latin American White cheese. A Review J. Dairy Sci, 64:552.

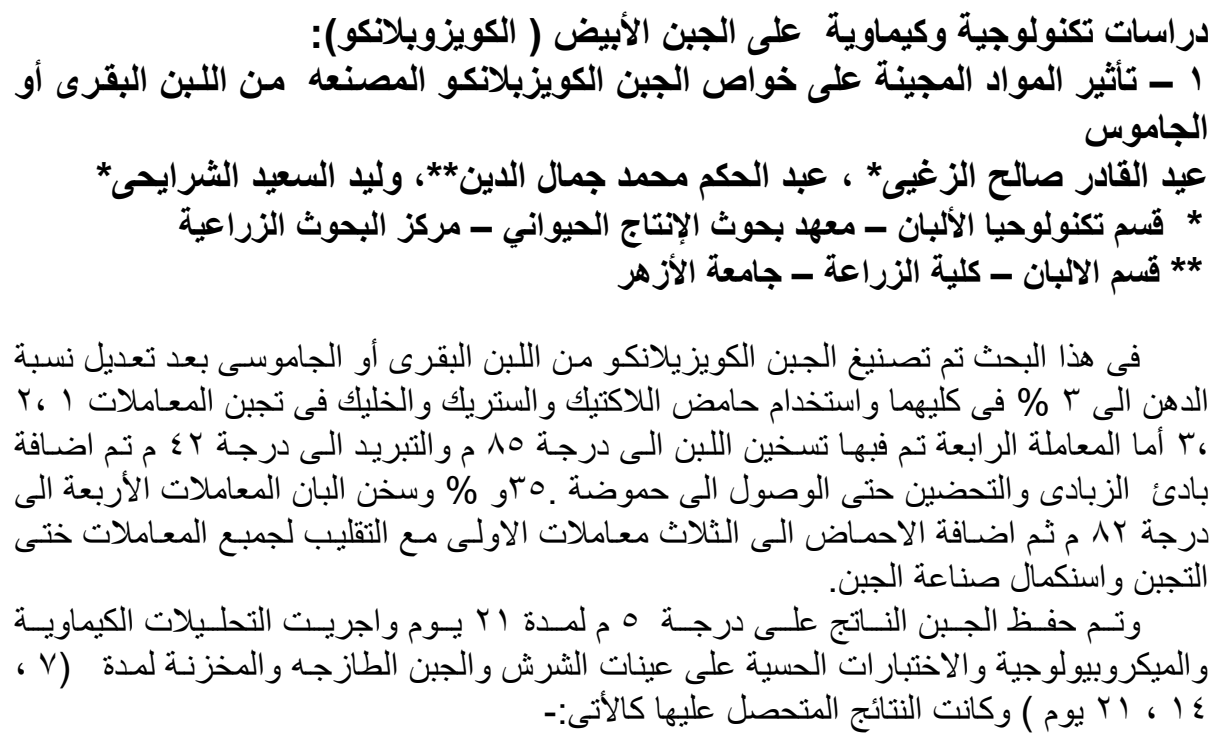




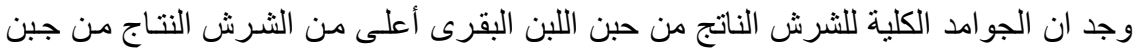

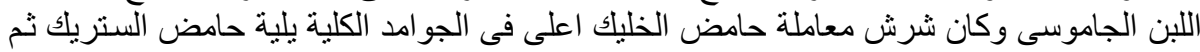

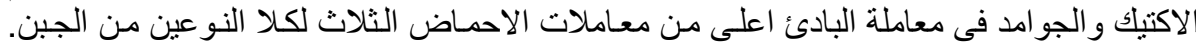

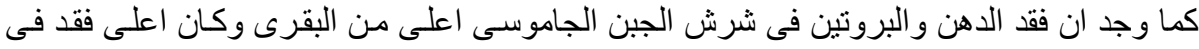

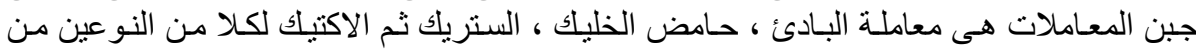

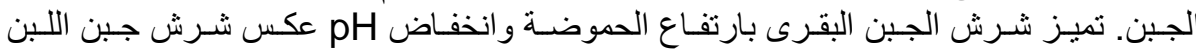

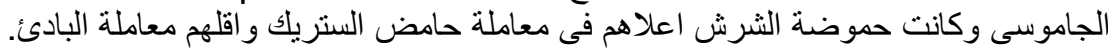

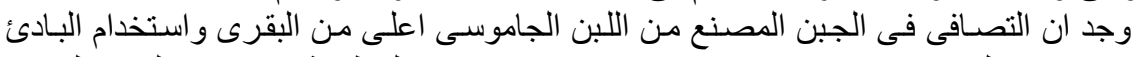

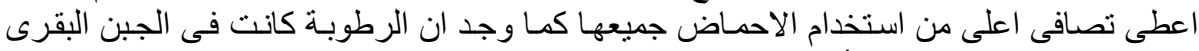

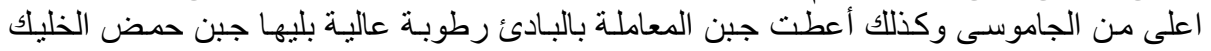
و الستريك و الاكتيك فى كلا النو النو عين من اللبن اللبن.

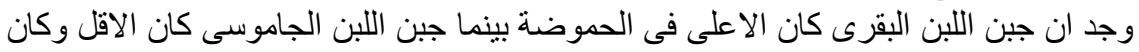

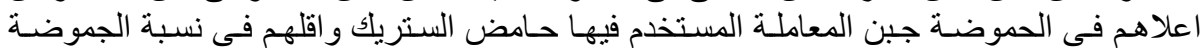

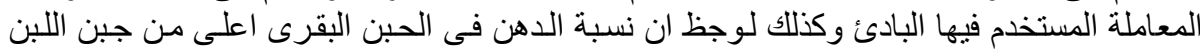

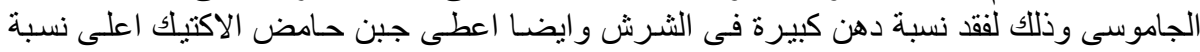

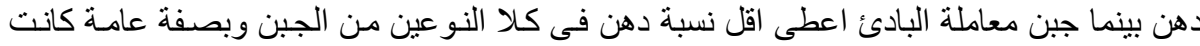

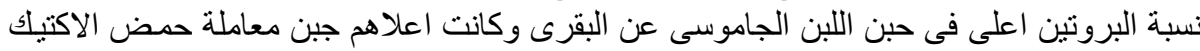

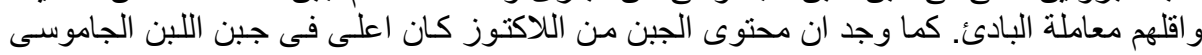

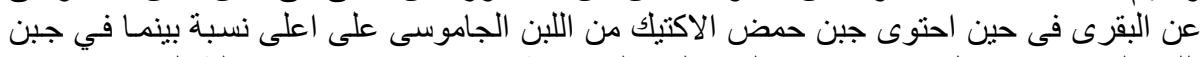

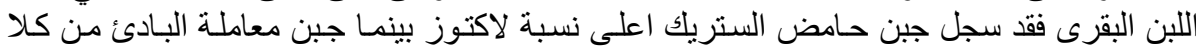

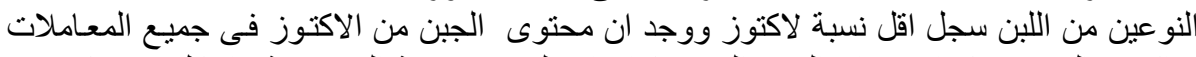

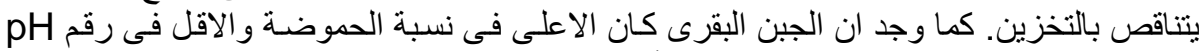

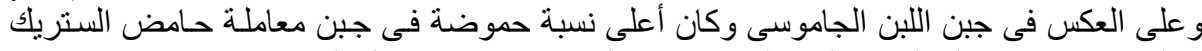

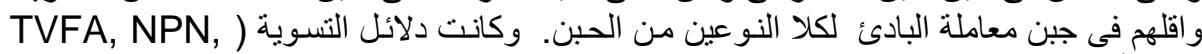

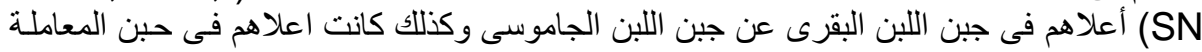

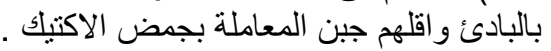

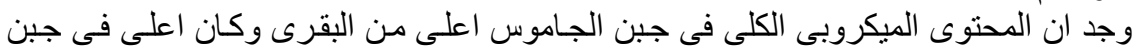

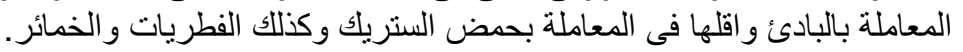

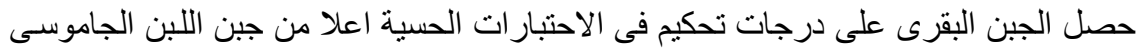

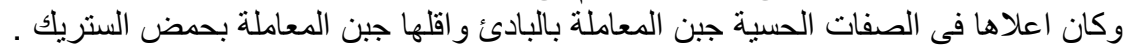

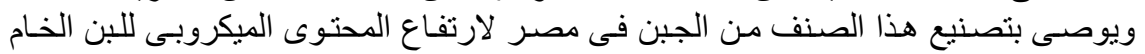

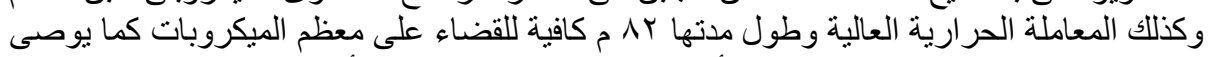

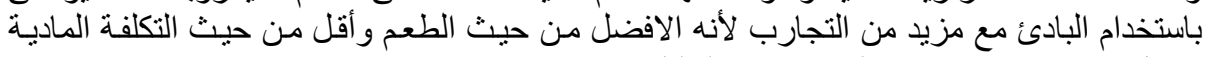
يفضل استخدام حمض الاكتيك و استبعاد الخليك. 